IP Periodica Polytechnica Civil Engineering

\author{
60(1), pp. 374,43 2016 \\ DOI: $10.3311 /$ PPci.7661 \\ Creative Commons Attribution (1) \\ RESEARCH ARTICLE
}

\section{Displacement of the Buildings According to Site-Specific Earthquake Spectra}

\author{
Ercan Işık, Mustafa Kutanis, İhsan Engin Bal
}

Received 13-08-2014, revised 02-04-2015, accepted 30-05-2015

\begin{abstract}
The probabilistic seismic hazard curves were based on appropriate attenuation relationships at rock sites with a probability of exceedance of $10 \%$ in 50 years in this study. Results from the model were compared to the response spectra proposed in Section 7 of TEC ' 07 and were found to differ in both amplitude and frequency content. The impact of these differences has been investigated with respect to building performance evaluation. Specifically, modal capacity diagrams and response spectra have been obtained for five buildings. Based on the diagrams and spectra, peak displacements have been calculated as well, revealing significant differences in the demand displacement curves of the buildings. As a result, damage estimates and predicted building performance will deviate from site specific performance to a greater degree. Using site-specific spectra and field data will be important for future earthquake-resistant design. One of the conclusions of the study is that the Code spectra do not offer a sufficient or comprehensive enough set of seismic demands and would lead to an under estimation of seismic hazard in the region of study. Therefore, site-specific design spectra for the region should be developed which reflect the characteristics of local sites.
\end{abstract}

\section{Keywords}

Seismic Hazard · Response Spectra · Lake Van · Peak Displacement

\section{Ercan Işık}

Faculty of Engineering, Department of Civil Engineering, Bitlis Eren University, 13100, Bitlis, Turkey

e-mail: ercanbitliseren@gmail.com

\section{Mustafa Kutanis}

Faculty of Engineering, Department of Civil Engineering, Sakarya University, 54187, Sakarya, Turkey

e-mail: kutanis@sakarya.edu.tr

\section{İhsan Engin Bal}

Institute of Earthquake Engineering and Disaster Management, Istanbul Technical University, Istanbul, Turkey

e-mail: iebal@itu.edu.tr

\section{Introduction}

The seismic risk of building stock is of growing interest for academia as well as for governments due to the increasing urbanization and concentration of populations in earthquake prone and vulnerable areas. Since 1999 İzmit earthquake, Turkey has become recognized as one of the most earthquake-prone regions in the world. This is true considering that most of the country is mapped as having probabilities of peak ground acceleration PGA (up to $9.8 \mathrm{~m} / \mathrm{sec}^{2}$ ).

Seismic hazard analysis of the earthquake-prone Eastern Anatolia region of Turkey has become more important due to its growing strategic importance as a global energy corridor and closer integration with the European Union. In this study Bitlis province is selected as the study area. The town of Bitlis, capital of the province, has a population of 70,000 (including surroundings) as of the year 2000. The town located $15 \mathrm{~km}$ away from Lake Van, along the steep slopes of the Bitlis River valley at an elevation of $1,400 \mathrm{~m}$.

The seismicity of Bitlis has been evaluated using a performance-based earthquake engineering (PBEE) approach in this study. PBEE seeks to improve seismic risk decision-making through assessment and design methods that have a strong scientific basis and present options in terms that stakeholders can understand and make informed decisions. Given the inherent uncertainty and variability in seismic response, it follows that a performance-based methodology should be formalized within a probabilistic basis. The framework has four main analysis steps: Hazard analysis, structural/nonstructural analysis, damage analysis and loss analysis. The first assessment step entails a hazard analysis, through which one evaluates one or more ground motion Intensity Measures (IM). Standard earthquake intensity measures (such as peak ground acceleration or spectral acceleration) are obtained through conventional probabilistic seismic hazard analyses. Typically, IM is described as a mean annual probability of exceedance, which is specific to the location and design characteristics of the facility [1]. 


\section{Local Geology and Seismicity of Bitlis}

The local geological soil conditions change the characteristics of surface seismic response. It is a known fact that this may cause damage on the existing structures built on these grounds [2]. The Lake Van Basin which contains Bitlis is located in the region known as the Bitlis Thrust Zone in geological terms. It is a collapsed tectonic basin which is related to the Eastern Taurus region [3]. Orogenic movements have occurred in the field until third phase of Miocene. Volcanic events have caused many faults to form, as well as depressions and large lakes in this period [4,5]. Metamorphic rock in the region belonging to the Bitlis Massif include the Upper Cretaceous AhlatAdilcevaz mélange and Ahlat conglomerate, Miocene Adilcevaz limestone, Pliocene-Quaternary volcanic rocks and alluvial deposits form the surface in Bitlis and surrounding region [6.7]. A geological map of Lake Van Basin is shown in Fig. 1.
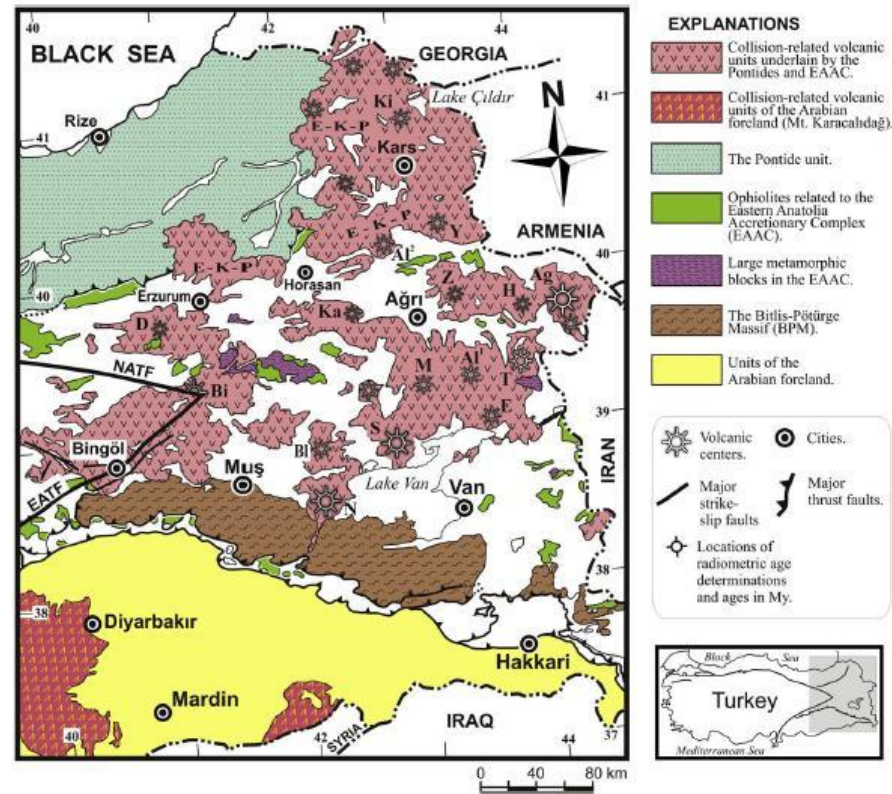

Fig. 1. Geological map of the Lake Van region. $\mathrm{N}-$ Nemrut Volcano, $\mathrm{S}-$ Süphan Volcano in the immediate vicinity of the lake. EATF - East Anatolian Fault; NATF - North Anatolian Fault 8

The general tectonic setting of Eastern Anatolia is controlled mainly by the collision of the Northerly-moving Arabian plate with the Anatolian plate along a deformation zone known as the Bitlis Thrust Zone (Fig. 2, Arrow below Bitlis Zagros Suture Zone). The collision drives the westward extrusion of the Anatolian plate along two well knows transform faults with known as the Bitlis Thrust Zone (Fig. 2, Arrow below Bitlis Zagros Suture Zone). The collision drives the westward extrusion of the Anatolian plate along two well know transform faults with different slip directions, the right-lateral North Anatolian (NAFZ) and the left-lateral East Anatolian Fault (EAFZ) zones, which join each other in Karlıova Triple Junction (KTJ) in eastern Anatolia (Fig. 2, letter K). To the east of KTJ, however, the compressional deformation is largely accommodated within the Eastern Anatolian Block through distributed NW-SE trending rightlateral faults and NE-SW trending left lateral faults representing escape tectonics, and shortening of the continental lithosphere along the Caucasus thrust zone. East-west trending Mush-Lake Van and Pasinler ramp basins constitute other conspicuous tectonic properties within the eastern Anatolia [9-[13].

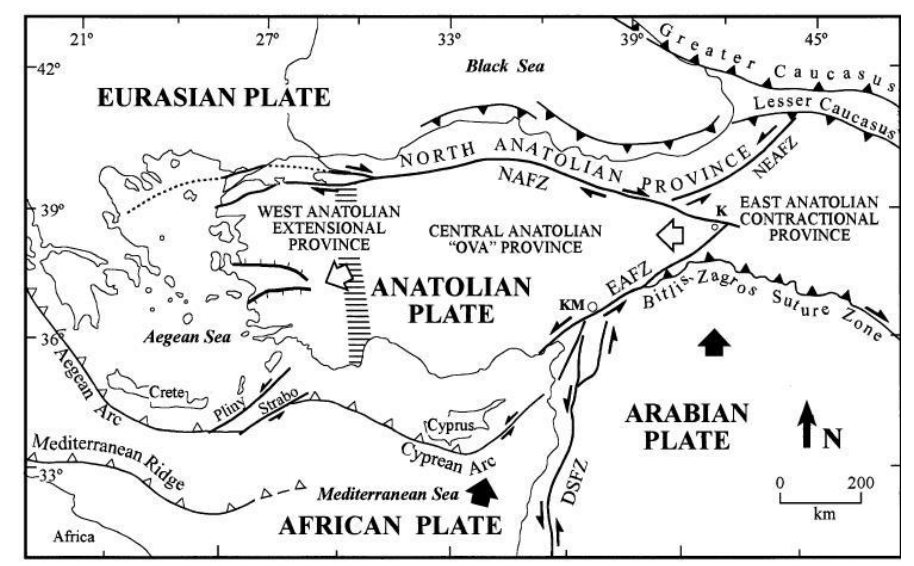

Fig. 2. Tectonic map of Turkey including major structural features [14]

The Lake Van basin has been seismically active region as indicated by historical sources. Table 1 tabulates the significant earthquakes occurred in Bitlis and surrounding area before 20th century.

Based on historical and instrumented earthquakes, Bitlis is constantly under the influence of both micro- and macro- earthquakes. Thus, it will not be difficult to say that Bitlis will remain under the influence of larger earthquakes [15]. Bitlis Centre City is in first degree of seismic zones in the current seismic hazard map of Turkey with a minimum effective peak horizontal ground acceleration of $0.40 \mathrm{~g}$.

\section{Site-Specific Design Spectra for Bitlis Province}

The seismic hazard analysis approach is based on the model developed originally by Cornell (1968) [16] who quantified hazard in terms of the probability of exceedance of a peak ground acceleration (PGA). The procedure for conducting a probabilistic seismic hazard analysis includes characterizing the seismic source, determining size distribution and rate of occurrence estimating ground motion, and lastly, analyzing probability.

In the current study, since the neotectonic faults are not identified in the research area clearly, earthquake sources are characterized as area source zones. Area seismic sources are often defined where specific fault data are not known, but seismicity does exist. Area sources assume that the rate of occurrence is uniform throughout. Therefore, every location within the area has equal probability that an event will occur. All seismic sources, that can generate strong ground shaking in Bitlis and surroundings, are classified into 7 areal seismic zones (Fig. 3). (1) Bitlis Zagros Suture zone; (2) Northern Bitlis thrust fault zone [17]; (3) Kavakbaş1Fault zone; (4) Malazgirt fault zone; (5) Ahlat and surrounding fault zone; (6) Suphan Fault zone ; and (7) Southern Van faults (Erçek fault, Kalecik fault, Edremit fault and Southern Boundary fault [18]. 
Tab. 1. The significant earthquakes in and around Bitlis before $20^{\text {th }}$ century

\begin{tabular}{|c|c|c|c|c|c|c|}
\hline No & Date & Lat. $\left({ }^{\circ}\right)$ & Lan. $\left({ }^{\circ}\right)$ & Location & M & 1 \\
\hline 1 & 461 & 39.10 & 42.50 & Malazgirt & & $x$ \\
\hline 2 & 1012 & 39.10 & 42.50 & Malazgirt & & VII \\
\hline 3 & 1101 & 38.50 & 43.50 & Ahlat - Van & & $\mathrm{VI}$ \\
\hline 4 & 1110 & 38.50 & 43.50 & Ahlat - Van & & VIII \\
\hline 5 & 1111 & 38.50 & 42.70 & Ahlat - Van & & IX \\
\hline 6 & 1208 & 38.70 & 42.50 & Ahlat-Van-Bitlis-Muş & 6.5 & \\
\hline 7 & 1245 & 38.74 & 42.50 & Ahlat - Bitlis- Van - Muş & & VIII \\
\hline 8 & 1246 & 38.90 & 42.90 & Lake Van (Ahlat - Erçiş -Van) & & VIII \\
\hline 9 & 1275 & 38.40 & 42.10 & Bitlis- Ahlat -Erciş - Van & & VII \\
\hline 10 & 1276 & 38.90 & 42.50 & Bitlis- Ahlat -Erciş - Van & & VIII \\
\hline 11 & 1282 & 38.90 & 42.90 & Ahlat - Erçiş & & VII \\
\hline 12 & 1345 & 39.10 & 42.50 & Malazgirt & & VIII \\
\hline 13 & 1363 & 38.70 & 41.50 & Muş andsurrounding & & IX \\
\hline 14 & 1415 & 38.50 & 43.00 & Van Gölü & & V \\
\hline 15 & 1439 & 38.50 & 42.10 & Nemrut & & VI \\
\hline 16 & 1441 & 38.35 & 42.10 & Nemrut & & VIII \\
\hline 17 & 1444 & 38.50 & 43.40 & Nemrut - Van & & $\mathrm{VI}$ \\
\hline 18 & 1546 & 38.50 & 43.40 & Van - Bitlis & & $\mathrm{V}$ \\
\hline 19 & 1582 & 38.35 & 42.10 & Bitlis and surrounding & & VIII \\
\hline 20 & 1646 & 38.50 & 43.40 & Van and surrounding & & VII \\
\hline 21 & 1647 & 39.15 & 44.00 & Van - Muş -Bitlis & & IX \\
\hline 22 & 1648 & 38.30 & 43.70 & Van and surrounding & 6,7 & VIII \\
\hline 23 & 1670 & 38.00 & 42.00 & Hizan - Siirt & 6,6 & \\
\hline 24 & 1682 & 38.40 & 42.10 & Bitlis & & \\
\hline 25 & 1696 & 39.10 & 43.70 & Çaldıran - Bitlis & 6,8 & $x$ \\
\hline 26 & 1701 & 38.50 & 43.40 & Van and surrounding & & VIII \\
\hline 27 & 1704 & 38.50 & 43.40 & Van & & VII \\
\hline 28 & 1705 & 38.40 & 42.10 & Bitlis & 6,7 & IX-X \\
\hline 29 & 1715 & 38.70 & 43.50 & Van - Erçiş & 6,6 & VIII \\
\hline 30 & 1869 & 38.40 & 42.10 & Bitlis andsurrounding & & VII \\
\hline 31 & 1871 & 38.50 & 43.40 & Van -Nemrut & 5,5 & VII \\
\hline 32 & 1881 & 38.50 & 43.40 & Van andsurrounding & 7,3 & IX \\
\hline 33 & 1884 & 37.50 & 42.50 & Bitlis - Pervari & 6,9 & \\
\hline 34 & 1891 & 38.80 & 42.50 & Malazgirt- Adilcevaz-Bitlis & 5,5 & VIII \\
\hline 35 & 1892 & 39.10 & 42.50 & Malazgirt - Muş & & VII \\
\hline
\end{tabular}

On any given fault within any given region, earthquakes occur at irregular intervals in time, and one of the basic activities in seismology has long been the search for meaningful patterns in the time sequences of earthquake occurrence [19]. Among a number of recurrence laws have been proposed, in this study, Gutenberg and Richter [20] law was used due to the fact that there is no available evidence to determine whether the Gutenberg-Richter or some other recurrence laws are correct. During any given interval in time, the general underlying pattern or distribution of size of events is that first described by Gutenberg and Richter, who derived an empirical relationship between magnitude and frequency of the form;

$$
\log N=a-b M
$$

where $N$ is the number of shocks of magnitude at least $M$ per unit time and unit area, and $\mathrm{a}$ and $\mathrm{b}$ are seismic constants for any given region [19].

In a seismic hazard modelling study of Bitlis, recurrence rates are estimated by using historical and digital records given a partial list in Table 1 and instrumental data. After the compilation of collected data, a plot of " $M$ " against " $\log N$ " was constructed and the best-fit line of the form of Eq. (1) was determined by regression analysis (Fig. 4).

In probabilistic seismic hazard analysis, beside magnitudefrequency relationship which is calculated for Bitlis province as $\log N=5.6247-0.7794 \mathrm{M}$, a relationships between magnitude and fault rupture parameters of length $L_{s u b}(\mathrm{~km})$, width $W(\mathrm{~km})$, area $A\left(\mathrm{~km}^{2}\right)$ and displacement $D(\mathrm{~m})$ is also required. In a study of a worldwide database of 244 earthquakes, for strike-slip fault types Wells and Coppersmith (1994) [21] obtained:

$$
M_{w}=4.33+1.49 \log L_{s u b} s=0.2
$$




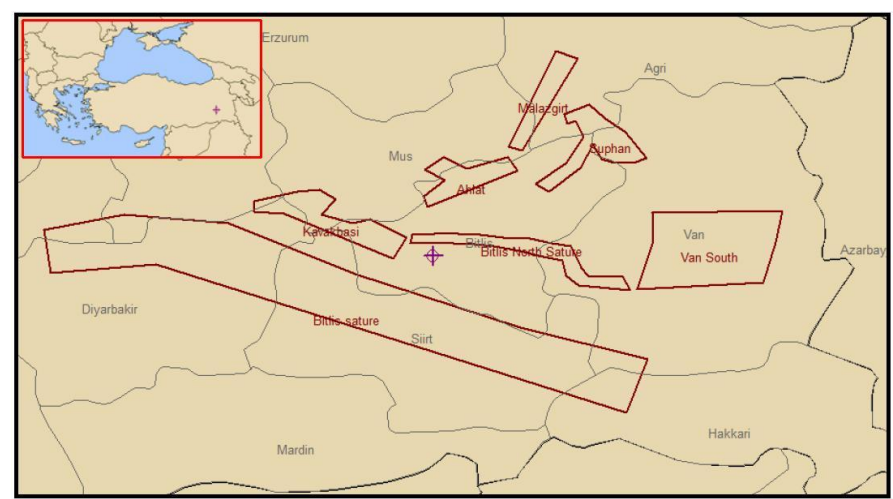

Fig. 3. Earthquake are all zones (Bitlis Suture, Van South, Bitlis North Sature, Kavakbasi, Ahlat, Malazgirt and Suphan) in Bitlis and surroundings

where $s$ is the residual standard deviation.

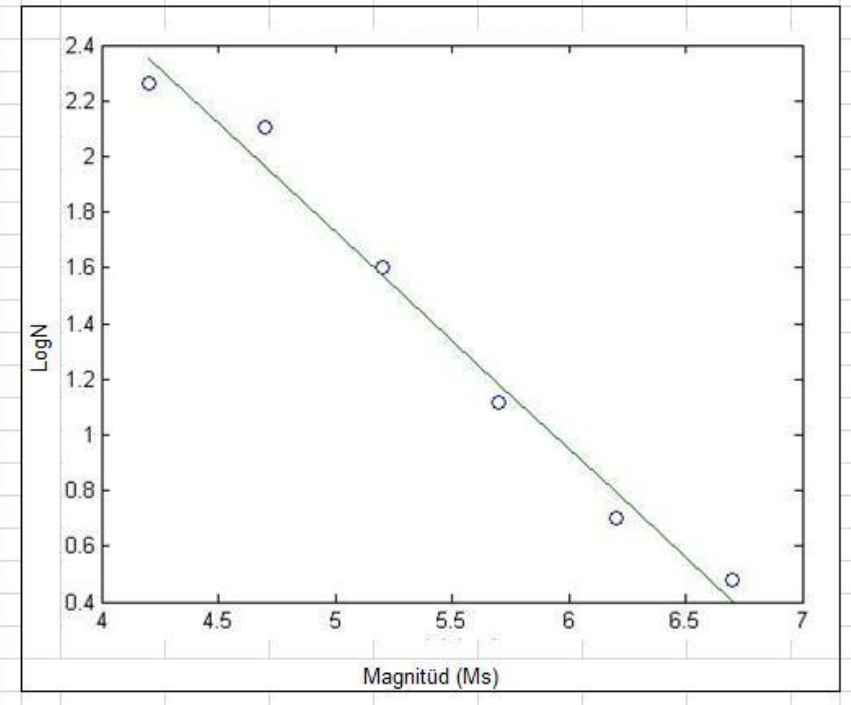

Fig. 4. Gutenberg-Richter magnitude-frequency relationship for earthquakes from Bitlis and surrounding data

In Eastern Anatolia region, previously recorded strong ground motion acceleration records are limited. Therefore, in the current analysis, worldwide applicable three empirical attenuation relationships are utilized to perform the seismic hazard analysis. Attenuation relationships for rock sites employed in this study are Abrahamson-Silva (1997) [22], Ambraseys et al. (2005) [23], Boore-Joyner-Fumal (1997) [24], Campell (2003) [25] and Idriss(2008) [26] (Fig. 5).

After the compilation of the seismic hazard analysis data, the procedure for conducting a probabilistic seismic hazard analysis, by using EZ-FRISK [27,28] software, was employed to produce the PGA as a function of return periods (Fig. 6), and uniform probability response spectra for selected return periods (Fig. 7) The results of probabilistic seismic hazard analysis for Bitlis are presented in terms of spectral responses at $5 \%$ damping for the return periods of 72, 474.6 and 2474.9 years (Fig. 7). The results are compared with the spectral responses proposed for seismic evaluation and retrofit of building structure in Turkey Earthquake Code (2007) Section 7 [29]. The results of probabilistic seismic hazard analyses revealed peak acceleration val-

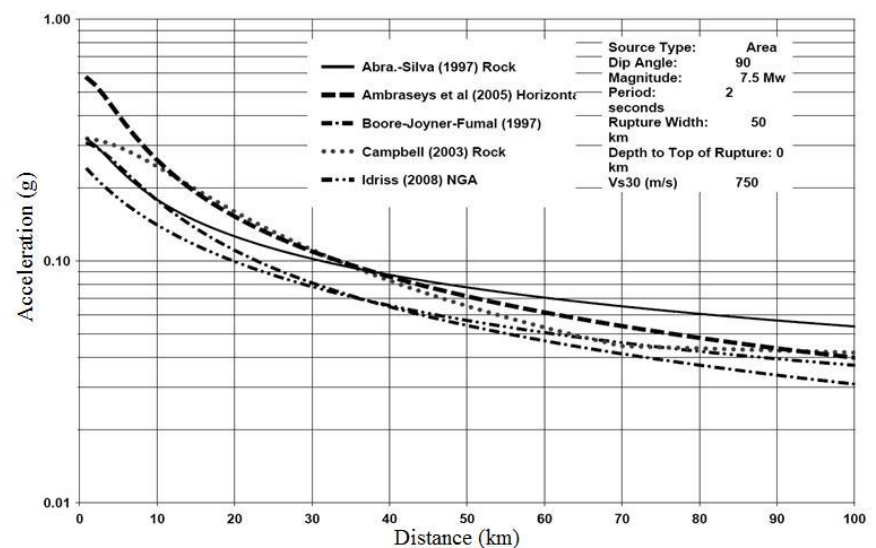

Fig. 5. Abra-Silva (1997), Ambraseys et al (2005), Boore-Joyner-Fumal (1997), Campell (2003) and Idriss (2008) attenuation relationships for rock sites.

ues for a typical rock site as $0.76 \mathrm{~g}$ for $50 \%$ probability of exceedance in 50 years, $1.61 \mathrm{~g}$ for $10 \%$ probability of exceedance in 50 years and $2.68 \mathrm{~g}$ for $2 \%$ probability of exceedance in 50 years. The obtained results are compared with the spectral responses proposed for seismic evaluation and retrofit of building structure in Turkey Earthquake Code, Section7 (Fig.7).

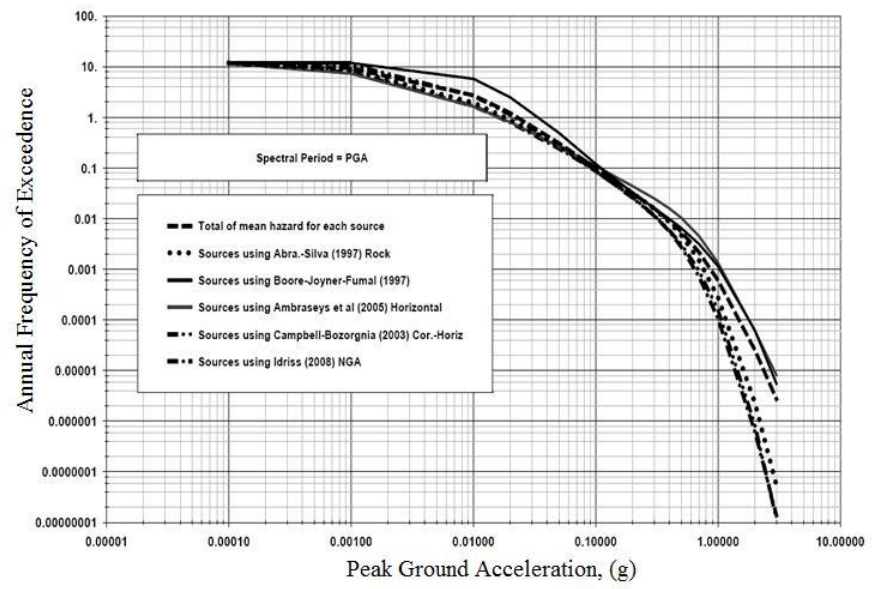

Fig. 6. Peak ground acceleration (PGA) at Bitlis with varying return periods.

\section{Calculation of Displacement of the Buildings Accord- ing to Spectra}

During the last two decades, performance based design and assessment methods have become rather more popular than during the era they were firstly proposed. In the near future, it is likely that when new generation seismic codes are released, performance based approach will be the most common tool for the design of new structures. Currently, however, performance based design tools suffer from a major drawback that their presentation of the seismic behavior is restricted by a single mode response. Therefore such methods can be reliably applied only to the two-dimensional response of low-rise, regular buildings.

The demand spectra that were used for determining the performance of buildings systems have shown the maximum response to earthquake ground motion during an earthquake. In performance based design and assessment methods the earth- 


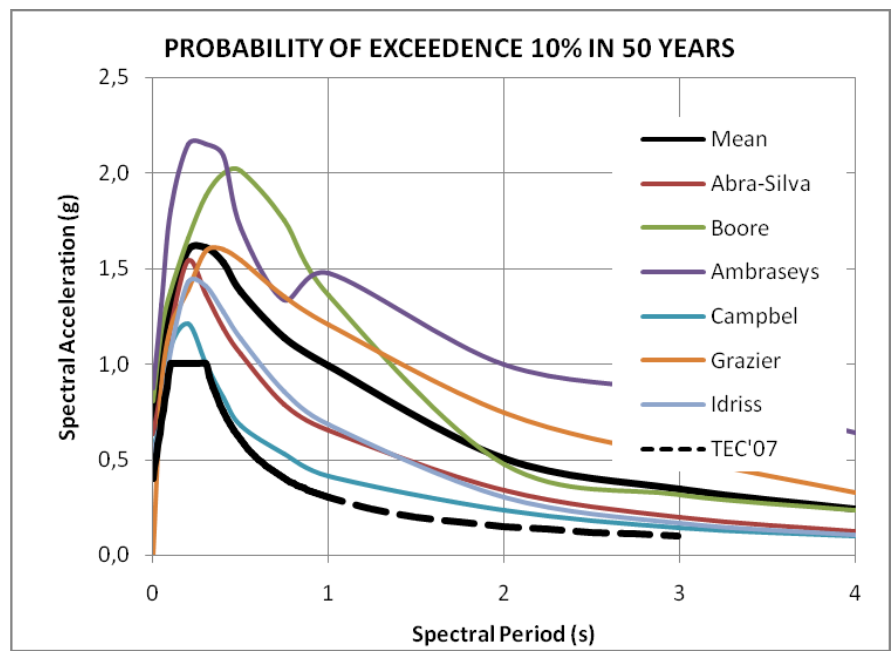

Fig. 7. Comparison of Spectral responses at $5 \%$ damping for the return period of 474.6 years in Bitlis

quake demand is first calculated. It is then necessary to determine the structural performance by comparing these demand values to deformation capacity for the selected performance levels. Building evaluations were performed separately for the spectrum obtained from the seismic hazard analysis and for design spectra that has been given in TEC'07. Modal capacity diagrams and response spectra have been obtained for five buildings. Peak displacements for these five buildings have been calculated based on capacity diagrams and response spectra. The displacement demands were calculated by using the equivalent displacement rule given in the TEC'07. Modal capacity diagram with coordinates given as “ a (acceleration) - $\mathrm{d}$ (displacement) and response spectra with coordinates given as " $S_{a}$ (spectral acceleration $)-S_{d}$ (spectral displacement) " are shown graphically for each building studied in Fig. 8- 17

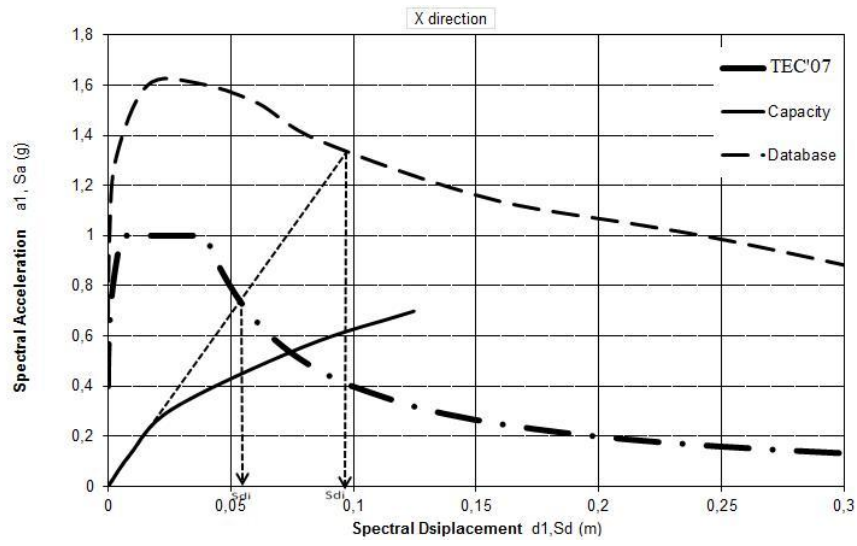

Fig. 8. Modal Capacity - Response Spectra diagrams for Building 1 in the $\mathrm{X}$ direction

The comparison of building peak displacements was given in Table 2.

\section{Conclusions}

By utilizing available data improved methods, a probabilistic seismic hazard analysis of Bitlis province in Turkey was performed. As a first step toward performance based earthquake

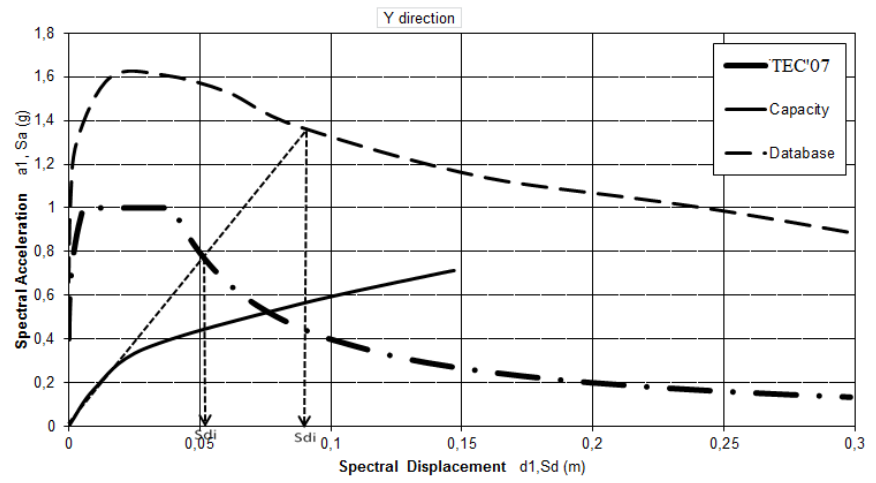

Fig. 9. Modal Capacity - Response Spectra diagrams for Building 1 in the $\mathrm{Y}$ direction

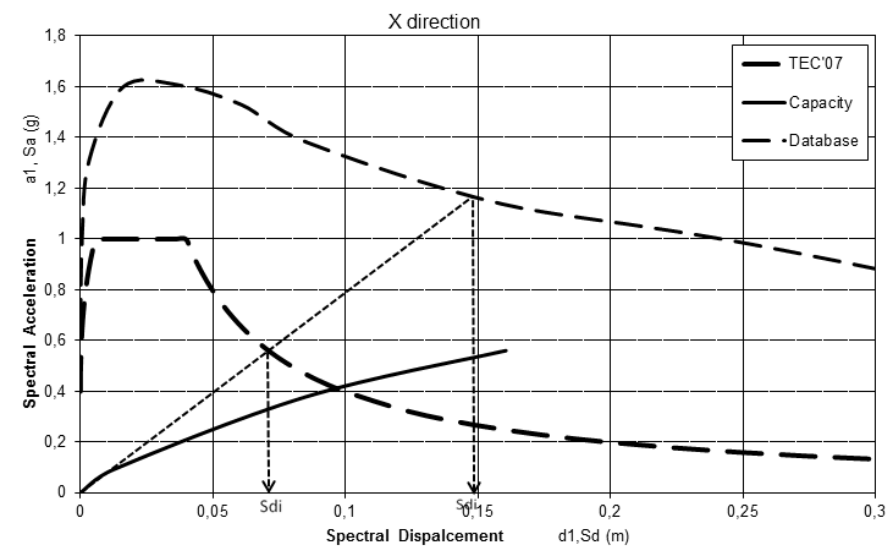

Fig. 10. Modal Capacity - Response Spectra diagrams for Building 2 in the $\mathrm{X}$ direction

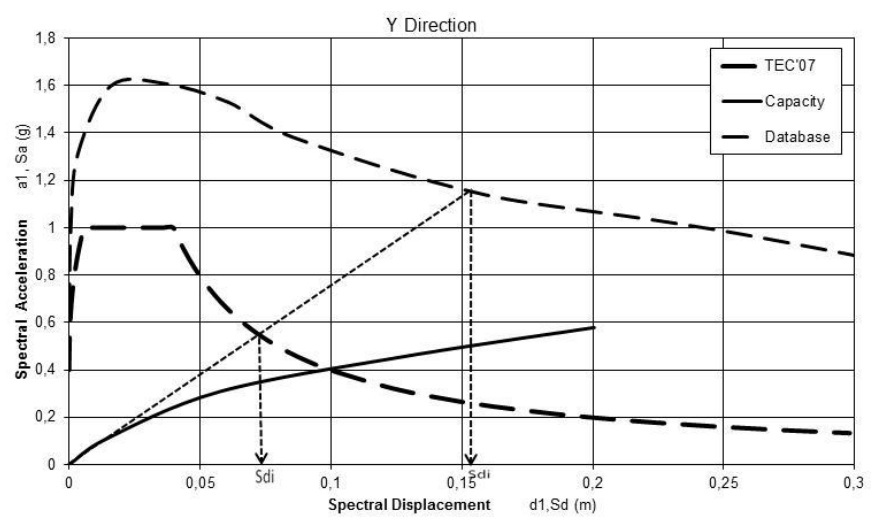

Fig. 11. Modal Capacity - Response Spectra diagrams for Building 2 in the $\mathrm{Y}$ direction

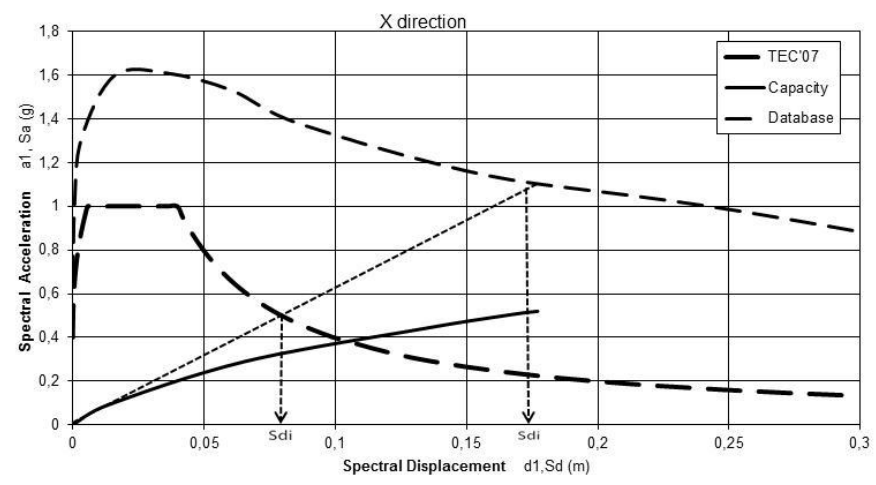

Fig. 12. Modal Capacity - Response Spectra diagrams for Building 3 in the $\mathrm{X}$ direction 


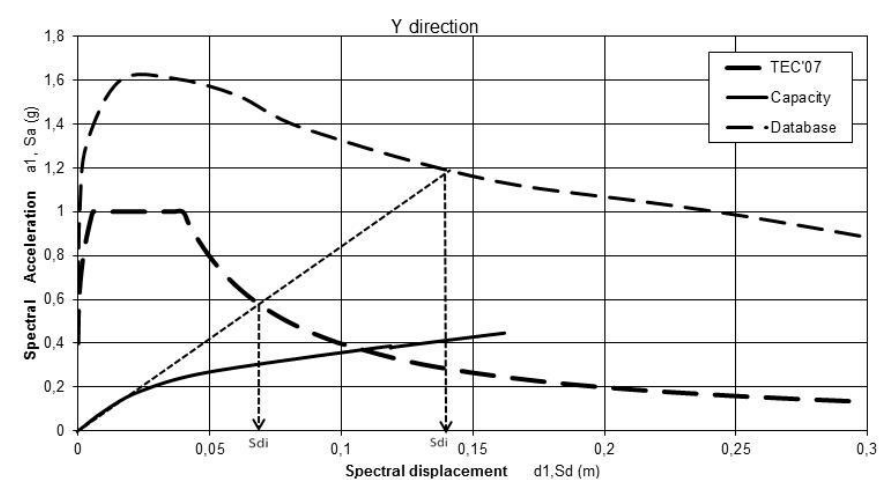

Fig. 13. Modal Capacity - Response Spectra diagrams for Building 3 in the $\mathrm{Y}$ direction

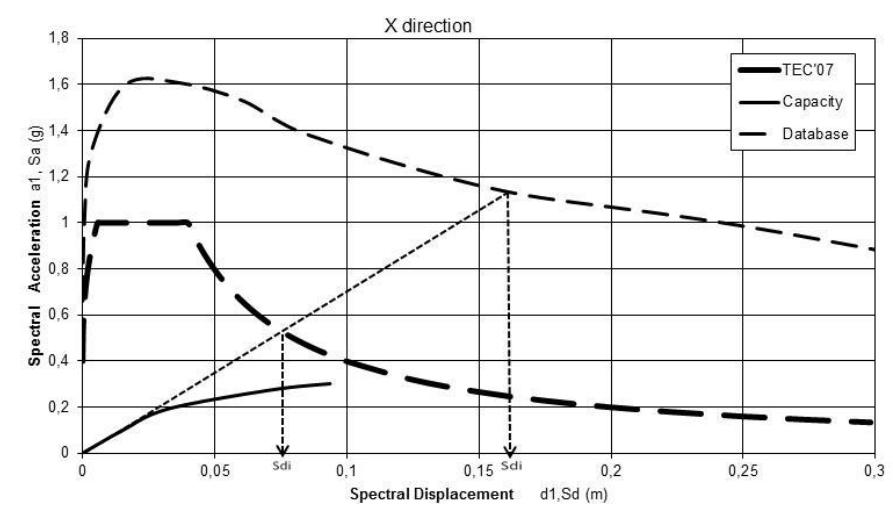

Fig. 14. Modal Capacity - Response Spectra diagrams for Building 4 in the $\mathrm{X}$ direction

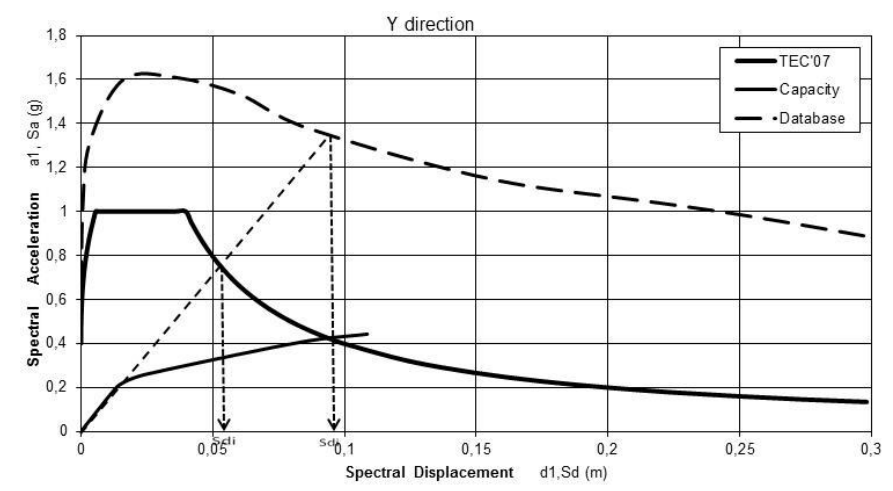

Fig. 15. Modal Capacity - Response Spectra diagrams for Building 4 in the $\mathrm{Y}$ direction

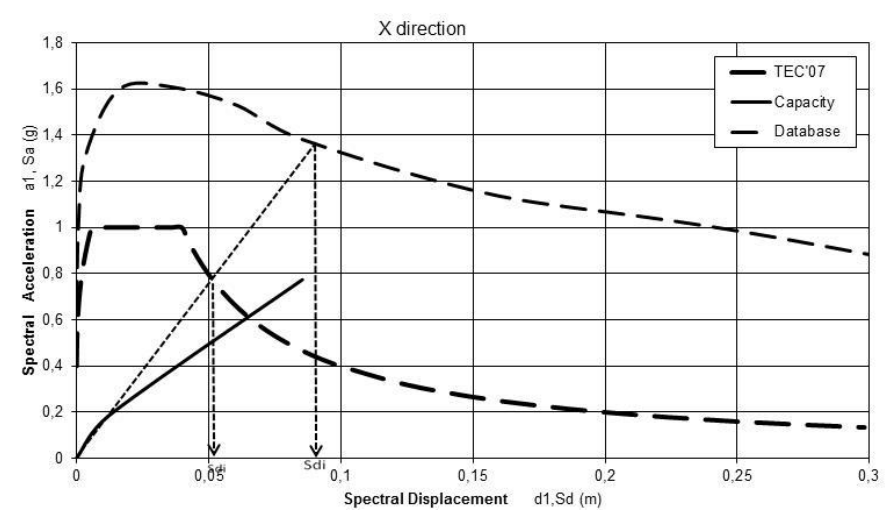

Fig. 16. Modal Capacity - Response Spectra diagrams for Building 5 in the $\mathrm{X}$ direction

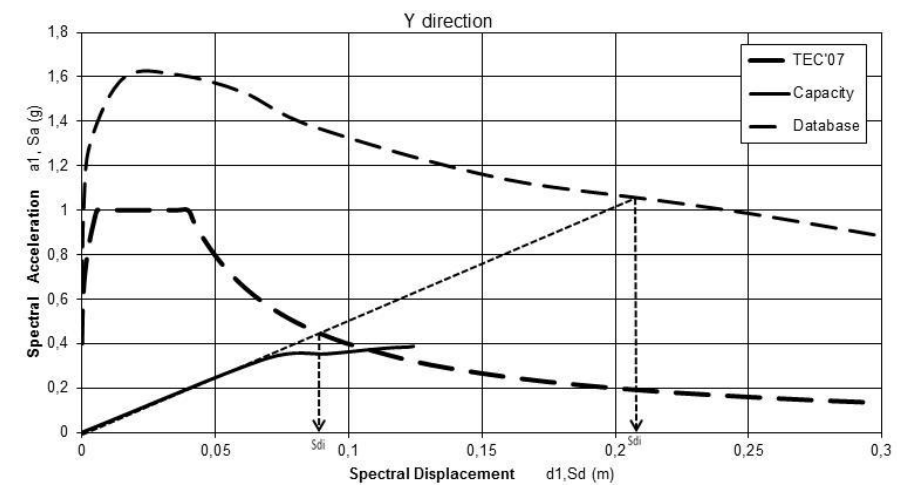

Fig. 17. Modal Capacity - Response Spectra diagrams for Building 5 in the $\mathrm{Y}$ direction

Tab. 2. Building's peak displacements for TEC' 07 and the response spectra obtained from this study

\begin{tabular}{cccccc}
\hline \multirow{2}{*}{$\begin{array}{c}\text { Building } \\
\text { Number }\end{array}$} & \multirow{2}{*}{ Direction } & \multicolumn{2}{c}{ TEC'07 } & \multicolumn{2}{c}{ DATABASE } \\
\cline { 3 - 6 } & & $S_{d e 1}$ & $u_{N 1}$ & $S_{d e 1}$ & $u_{N 1}$ \\
\hline \multirow{2}{*}{1} & $\mathrm{X}$ & 0,056 & 0,073 & 0,09 & 0,1171 \\
& $\mathrm{Y}$ & 0,052 & 0,067 & 0,085 & 0,1101 \\
\hline \multirow{2}{*}{2} & $\mathrm{X}$ & 0,072 & 0,0923 & 0,148 & 0,1897 \\
& $\mathrm{Y}$ & 0,079 & 0,1046 & 0,152 & 0,2013 \\
\hline \multirow{2}{*}{3} & $\mathrm{X}$ & 0,08 & 0,1073 & 0,17 & 0,2281 \\
& $\mathrm{Y}$ & 0,069 & 0,091 & 0,142 & 0,1874 \\
\hline \multirow{2}{*}{4} & $\mathrm{X}$ & 0,079 & 0,0998 & 0,157 & 0,1984 \\
& $\mathrm{Y}$ & 0,051 & 0,066 & 0,092 & 0,1195 \\
\hline \multirow{2}{*}{5} & $\mathrm{X}$ & 0,053 & 0,0675 & 0,091 & 0,1159 \\
& $\mathrm{Y}$ & 0,088 & 0,113 & 0,206 & 0,2655 \\
\hline
\end{tabular}

engineering, it is well understood that the Code-proposed spectra are not sufficient to represent earthquake demand in the performance evaluation. The results of this work will form the basis for the replacement of the existing earthquake design spectra in evaluation of earthquake performances of the existing buildings in Bitlis province.

In this study, since active faults are not identified clearly, regional areas were used as an earthquake source zones. Future work will increase the resolution of the seismotectonic model by adding specific active faults. The obtained results are compared with the spectral responses proposed for seismic evaluation and retrofit of building structure in Turkish Earthquake Code, Section 7 and the amplitude and frequency range was different from each other. Modal capacity diagrams and response spectra have been obtained for five buildings. Peak displacements for these five buildings have been calculated based on capacity diagrams and response spectra. Results show that there were significant changes in the demand displacement of buildings. Therefore, damage estimates and building performance will better reflect real values for the buildings which did not meet the demand displacement (Fig. 18).

Using specific spectra obtained from site-specific investigation will be important for earthquake-resistant design of structures. At the end of this study, it is anticipated that for the performance evaluation of the existing structures, the Code-proposed earthquake response spectra are not sufficient and current esti- 


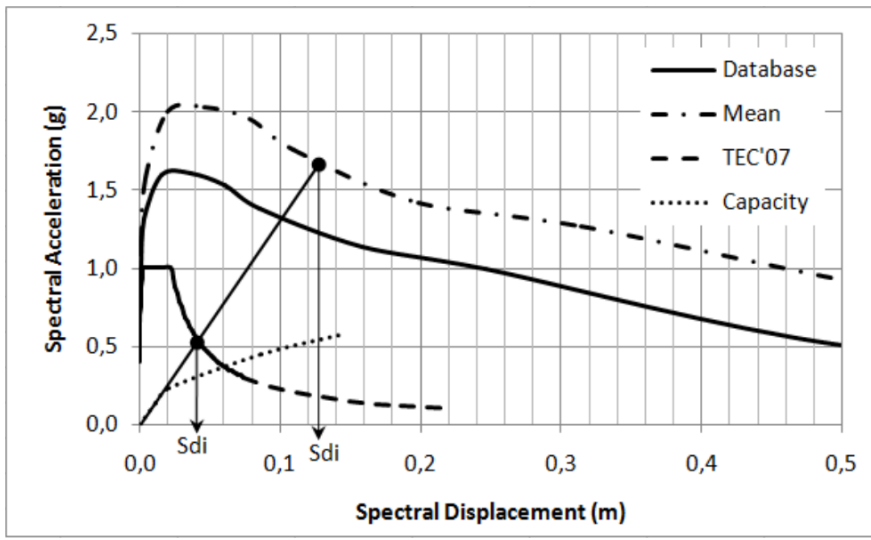

Fig. 18. Comparison of demand displacement of the earthquake

mations show that the potential seismic hazard in this area of the Turkey is underestimated by the code. Therefore, site-specific design spectra for the region should be developed, especially for local sites.

\section{References}

1 Moehle J, Deirlein GG, A Framework Methodology For PerformanceBased Earthquake Engineering, In: 13th World Conference on Earthquake Engineering; Vancouver, Canada, 2004, pp. 3812-3814.

2 Borcherdt RD, Influence of Local Geology in the San Fransisco Bay Region, California on Ground Motion Generated by the Loma Prieta Earthquake of October 17, 1989, In: Proceedings of International Symposium on Safety of Urban Life and Facilities; Tokyo, Japan, 1990, pp. 1-2.

3 Özkaymak Ç, Sağlam A, Köse O, Van Gölü doğusu aktif tektonik özellikleri, ATAG-7, Aktif Tektonik Araştırma Grubu, 7, (2003), 01-03. (in Turkish).

4 Faccenna C, Bellier O, Martinod J, Piromallo C, Regard V, Slab detachment beneath eastern Anatolia: A possible cause for the formation of the North Anatolian fault, Earth and Planetary Science Letters, 242(1-2), (2006), 85-97, DOI 10.1016/j.eps1.2005.11.046

5 Köse O, Van gölü yakın çevresinin coğrafyası, DAJEO-2004, Van Gölü Havzası Jeotraversleri Çalıştay Kitapçığı, (2004), 1-6. (in Turkish).

6 Jeo-Masif, Bitlis ili merkez ilçesi değişik parselleri için jeoteknik raporları, Jeo-Masif Ankraj İnş., ve Taah. Ltd. Şti., 2003. (in Turkish).

7 T.C. Başbakanlık Toplu Konut İdaresi Başkanlığı, Bitlis Rahva 2. Bölge 272 adet konut adaiçi ve genel altyapı ile çevre düzenlemesi inşaatı alanının zemin ve temel etüdü raporu, T.C. Başbakanlık Toplu Konut İdaresi Başkanlığı, 2006. (in Turkish).

8 Litt T, Krastel S, Sturm M, Kipfer R, Örçen S, Heumann G, Franz So, Ülgen UB, Paleovan, international continental scientific drilling program (ICDP):site survey results and perspectives, Quaternary Science Reviews, 28(15), (2009), 1555-1567, DOI 10.1016/j.quascirev.2009.03.002

9 Şengör AMC, Görür N, Şaroğlu F, Strike-slip faulting and related basin formation in zones of tectonic escape: Turkey as a case study, in: strikeslip faulting and basin formation, Soc. Econ. Pa., 37, (1985), 227-264, DOI 10.2110/pec.85.37.0227

10 Barka A, Kadinsky-Cade K, Strike-slip fault geometry in Turkey and its influence on earthquake activity, Tectonics, 7, (1988), 663-684, DOI 10.1029/2005JB004051

11 McClusky S, Balassanian S, Barka A, Demir C, Ergintav S, Georgiev I, Gürkan O, Hamburger M, Hurst K, Kahle H, Kastens K, Nadariya M, Ouzouni A, Paradissis D, Peter Y, Prilepin M, Reilinger R, Sanli I, Seeger H, Tealeb A, Toksöz MN, Veis G, GPS constraints on plate kinematics and dynamics in the Eastern Mediterranean and Cau- casus, Journal of Geophysical Research, 105, (2000), 5695-5719, DOI 10.1029/1999JB900351

12 Reilinger R, McClusky S, Vernant P, Lawrence S, Ergintav S, Cakmak R, Ozener H, Kadirov F, Guliev I, Stepanyan R, Nadariya M, Hahubia G, Mahmoud S, Sakr K, ArRajehi A, Paradissis D, Reilinger R, AlAydrus A, Prilepin M, Guseva T, Evren E, Dmitrotsa A, Filikov SV, Gomez F, Al-Ghazzi R, Karam G, GPS constraints on continental deformation in the Africa-Arabia-Eurasia continental collision zone and implications for the dynamics of plate interactions, Journal of Geophysical Research, 111, (2006), 1978-2012, DOI 10.1029/2005JB004051

13 Utkucu M, Implications for the level change triggered moderate $(M \geq 4.0)$ earthquakes in Lake Van Basin, Eastern Turkey, Journal of Seismology, 10, (2006), 105-117, DOI 10.1017/s10950-005-9002-y

14 Bozkurt E, Neotectonics of Turkey - a synthesis, Geodinamica Acta, 14, (2001), 3-30, DOI 10.1016/S0985-3111(01)01066-X

15 Işık E, Aydın MC, Bakış A, Özlük MH, The faults near Bitlis and seismicity of the region, BEU Journal of Science, 1(2), (2012), 153-169.

16 Cornell CA, Engineering seismic hazard analysis, Bulletin of the Seismological Society of America, 59(5), (1968), 1583-1606.

17 Dhont D, Chorowicz J, Review of the neotectonics of the Eastern Turkish - Armenian plateau by geomorphic analysis of digital elevation model imagery, International Journal of Earth Sciences, 95, (1996), 34-49, DOI 10.1007/s00531-005-0020-3

18 Utkucu M, Durmuş H, Yalçın H, Budakoğlu E, Işık E, Coulomb static stress changes before and after the 23 October 2011 Van, eastern Turkey, earthquake ( $M W=7.1)$ : implications for the earthquake hazard mitigation, Natural Hazards Earth System Science, 13, (2013), 1889-1902, DOI 10.5194/nhess-13-1889-2013

19 Dowrick D, Earthquake Risk Reduction, John Wiley \& Sons; England, 2003.

20 Gutenberg B, Richter CF, Frequency of earthquakes in California, Bulletin of Seismology Society America, 34, (1944), 185-188.

21 Wells DL, Coppersmith KJ, New empirical relationships among magnitude, rupture length, rupture width, rupture area and surface displacement, Bulletin of Seismology Society America, 84(4), (1994), 974-1002.

22 Abrahamson NA, Silva W, Empirical response spectral attenuation relations for shallow crustal earthquakes, Seismological Research Letters, 68(1), (1997), 94-127, DOI 10.1785/gssrl.68.1.94

23 Ambraseys NN, Douglas J, Sarma S, Smit PM, Equations for the estimation of strong ground motions from shallow crustal earthquakes using data from Europe and the Middle East: horizontal peak ground acceleration and spectral acceleration, Bulletin of Earthquake Engineering, 3(1), (2005), 1-53, DOI 10.1007/s10518-005-0183-0

24 Boore DM, Joyner WB, Fumal TE, Equations for estimating horizontal response spectra and peak acceleration from Western North American earthquakes: A summary of recent work, Seismological Research Letters, 68(1), (1997), 128-153, DOI $10.1785 / \mathrm{gssrl} .68 .1 .128$

25 Campell KW, Prediction of strong ground motion using the hybrid empirical method and its use in the development of ground-motion (attenuation) relations in Eastern North America, Bulletin Seismological Society of America, 93(3), (2003), 1012-1033, DOI $10.1785 / 0120020002$

26 Idriss IM, An NGA empirical model for estimating the horizontal spectral values generated by shallow crustal earthquake, Earthquake Spectra, 24(1), (2008), 217-242, DOI $10.1193 / 1.2924362$

27 EZ-FRISK User's Manual, Risk Engineering, Inc, 1997.

28 Mc Guire R, Seismic hazard and risk analysis, Earthquake Engineering Research Institute; Oakland, CA, 2004.

29 Turkish earthquake code-specification for structures to be built in disaster areas, Republic of Turkey, Ministry of Environment and Urbanisation; Ankara, Turkey, 2007. 